Article

\title{
Efficacy of Landfill Tax and Subsidy Policies for the Emergence of Industrial Symbiosis Networks: An Agent-Based Simulation Study
}

\author{
Luca Fraccascia *, Ilaria Giannoccaro and Vito Albino \\ Department of Mechanics, Mathematics, and Management, Politecnico di Bari, Viale Japigia 182, 70126 Bari, \\ Italy; ilaria.giannoccaro@poliba.it (I.G.); vito.albino@poliba.it (V.A.) \\ * Correspondence: luca.fraccascia@poliba.it; Tel.: +39-080-596-2743
}

Academic Editors: Giuseppe Ioppolo, Marian Chertow and Frank Boons

Received: 24 January 2017; Accepted: 25 March 2017; Published: 30 March 2017

\begin{abstract}
Despite the theoretical value of industrial symbiosis (IS), this approach appears to be underdeveloped in terms of practical applications. Different attempts to stimulate IS in practice are noticed, one of them consisting in the application of adequate policy measures. This paper explores the efficacy of two specific policies (landfill tax and economic subsidy for IS exchanges) in supporting the emergence of self-organized industrial symbiosis networks (ISNs). We frame the ISNs as complex adaptive systems and we design an agent-based model to simulate their emergence. We use a real case study and, by means of the simulation model, we assess how the two policy measures are able to enhance the formation of spontaneous IS relationships, thereby forcing the emergence of the ISN. Results show that both policy measures have a positive effect in all scenarios considered, but the extent is strictly dependent on the environmental conditions in which IS relationships occur. The economic implications for the government are finally discussed.
\end{abstract}

Keywords: industrial symbiosis; self-organized industrial symbiosis networks; self-organization and emergence; policy measures; agent-based simulation; enterprise input-output approach

\section{Introduction}

Industrial symbiosis (IS) is a subfield of industrial ecology that engages separate industries in a collective approach to competitive advantage, involving physical exchanges of materials, energy and services [1]. In particular, wastes generated by one firm can be used by other firms to replace production inputs or be exploited to generate new products [2]. The IS practice provides the involved firms with economic benefits, but at the same time creates environmental and social benefits for the entire community [3-6]. Aware of all these benefits, the European Commission strongly recommends the adoption of IS practice $[7,8]$.

The network of firms connected by waste exchanges makes up an industrial symbiosis network (ISN) [9]. Within an ISN, firms are involved in multiple IS relationships contemporaneously, and often belong to different industries, so that IS becomes a practice extending collaboration above the traditional supply chain level [10]. ISNs can be distinguished in two types based on the formation mechanism: (i) the top-down ISNs, designed by a central authority; and (ii) the self-organized ISNs, which are allowed to emerge from the bottom, as the result of a self-organization process undertaken by firms, each of them driven by the willingness to gain economic advantages through IS exchanges [11,12]. Empirical cases demonstrate that both these types can be successful $[3,13]$.

However, in both cases it is critical that IS relationships among firms are feasible from the technical, economic and legal point of view [14]. Since there are many factors that negatively affect these 
issues $[9,15,16]$, the IS approach is still underdeveloped in terms of practical applications compared to its theoretical opportunities [17].

A way to stimulate IS in practice is by means of policy actions. Policy makers can play a critical role to this end [18-21]. They can directly manage the IS project to promote and sustain a top-down ISN, such as in the case of Chinese and Korean Eco-Industrial Parks [22-24]. As to a self-organized ISN, they can stimulate the creation of an environment favorable to the spontaneous development of IS relationships among firms, by means of policy measures $[3,20]$. Whilst the positive effect of the policy interventions on top-down ISNs has been clearly demonstrated in the literature, the effects of the policy measures on the emergence of self-organized ISNs are still not sufficiently investigated [25]. To the best of our knowledge, there are very few studies quantifying the effect of the policy measures both on the adoption of the IS approach as well as on the economic effect for the government. This is a significant limit, since the self-organized IS approach is actually considered as the most promising one, thanks to its ability to be more resilient to perturbations such as changes in production levels, in symbiotic flows, in the dimension and the number of the actors involved [26]. Therefore, more investigation on the topic is mandatory.

In particular, this paper aims to explore the extent to which different policy measures positively influence the emergence of self-organized ISNs. We consider two measures: (i) the landfill tax; and (ii) the economic subsidy for IS exchanges. In approaching this issue, we frame the self-organized ISNs as complex adaptive systems (CASs) $[27,28]$, i.e., as networks of adaptive agents (firms) that emerge over time into coherent forms through interaction, without a central agent deliberately managing the system [29-31]. In doing so, ISNs are studied as an emergent process, arising from the spontaneous decisions of independent but interconnected firms. In particular, we use an agent-based model (ABM) to simulate the emergence of the ISN, studying the effect of the two policy measures on the formation of stable IS relationships in environments characterized by diverse levels of uncertainty and turbulence. Both literature and empirical observations in fact confirm that these aspects are critical in affecting the formation of IS relationships [28,32,33].

The paper is organized as follows. Section 2 presents the theoretical background. Section 3 presents the ABM model, the policy measures, the empirical case study and the simulation scenarios. Results and discussion are given in Section 4. Finally, conclusions are provided in Section 5.

\section{Theoretical Background}

\subsection{A complex Adaptive Systems Approach for Self-Organized ISNs}

CASs are networks of adaptive agents that emerge over time into coherent forms through interaction, without any singular entity or central control mechanism deliberately managing the overall system [29-31]. These systems are "adaptive" because they are able to change over time, creating new forms of emergent order consisting of new structures and patterns, in order to increase their fitness with the environment. Adaption is possible thanks to self-organization: in fact, the new order arises from the autonomous interactions among agents, which are not externally imposed on the system [34]. The main properties of CASs are: the existence of interconnected agents with different attributes and actions, self-organization, adaptation, emergence, non-linearity and path dependence [34-36].

Natural ecosystems and supply chains are examples of CASs [37-42] that exhibit strong similarities with ISNs [43-45]. Recently, self-organized ISNs have been also recognized as CASs, where firms are agents who interact with each other in exchanging wastes. Framing the ISN as a CAS means that it is the result of a self-organized process, where any generic firm autonomously makes the decision to establish a symbiotic relationship with another firm, without any deliberate planning performed by a central entity, such as a leading firm or the government. This decision is driven by the firm willingness to achieve economic benefits by means of IS relationship [46,47]. By establishing IS exchanges, firms can in fact enhance their production efficiency [48] and reduce their production costs so achieving competitive advantage $[4,49]$. However, they should also take into account that 
forming IS relationships generates additional transaction costs, due to the search of the symbiotic partner, the negotiation of the economic clauses for the waste exchange and the need to monitor the relationship $[27,50,51]$. Thus, it may happen that firms could decide to not create IS relationships due to the high amount of transaction costs [51]. Finally, the willingness to cooperate in IS exchanges can be also influenced by idiosyncratic organizational factors, such as the desired size of capital invested in IS projects, the payback time of the investment and the return on investment [3].

\subsection{Agent-Based Modeling}

Agent-based modeling is one of them most suited technique to study CASs [52]. In ABMs, the agent is mainly characterized by: (i) a given set of goals and actions to accomplish; and (ii) a given set of rules of social engagement, driving the interactions with other agents and the environment $[53,54]$. The complex system behavior spontaneously emerges from the interactions among the agents and between the agents and the environment, rather than to be defined by the modeler [55]. This allows investigation of the system dynamics in a way that analytical models cannot do. Applications of ABM span a broad range of disciplines such as economic systems [56], finance [57], marketing [58] and manufacturing [59]. In particular, the ABM approach was adopted to study cooperation dynamics within supply chains and industrial districts [60-63]. Based on the above, such an approach appears to be very suited to analyzing the ISN dynamics [64-66]. In this regard, the ABM approach was recently adopted to explore the efficacy of contractual mechanisms in fostering the development of self-organized ISNs [28], to study the evolution of ISNs over time [67] and to investigate how the redundancy in IS linkages can affect the economic and environmental benefits created by these networks [51].

\subsection{Policy Measures Supporting Self-Organized ISNs}

Public policies can promote the self-organized IS practice by creating a favorable environment for the spontaneous development of IS relationships [11,68-70]. In particular, the literature has developed three kinds of policy measures: (i) regulatory instruments; (ii) economic instruments; and (iii) voluntary instruments. Regulations and legal frameworks compel firms to implement IS practice, for instance banning specific wastes from landfills, thereby forcing firms to implement different strategies for their disposal $[18,20,71]$. Economic instruments motivate firms to implement IS practice by increasing the net economic benefits stemming from IS exchanges. Examples of these instruments are landfill taxes $[18,20]$, economic subsidies for studying feasibility conditions of IS projects [72], building facilities [22], financing IS transactions [23] and fiscal incentives for firms adopting IS practice [3]. Finally, voluntary instruments aim to promote firms to implement IS exchanges, making easier the creation of IS relationships. Examples of these instruments are databases and services matching demand and supply of wastes [3,73,74].

Although all these policy measures have shown to affect IS development, the extent of this impact is not clear enough. Empirical evidence suggests that the extent could depend on specific environmental conditions [25], which influence the technical, economic and cultural factors necessary to the formation of an IS relationship [69], and also affect the emergence of stable IS relationships among firms. For example, since high uncertainty and turbulence of the environment make unclear the economic benefits associated with IS relationships, ISNs are very unlikely to emerge in such conditions [28,32,33,51].

Thus, we are interested to study the efficacy of two economic policy measures (landfill tax and economic subsidy) in supporting the emergence of ISNs in scenarios characterized by different conditions of uncertainty and turbulence of the environment.

\section{Methods}

In this section, we present the agent-based model of a generic ISN, the agents' dynamics and the policy measures investigated. We also give details on empirical data used to calibrate the simulation model and we describe the simulation plan. 


\subsection{The Agent-Based Model of a Generic ISN}

To develop our model, we refer to the agent-based model by Albino et al. [28], which simulates the emergence of self-organized ISNs. Such a model considers an industrial network made up of $N$ firms. Each firm produces a single main product sold on the final market, fulfilling a stochastic customer demand. The production process requires a single input, purchased from the external supply market, and generates a single waste, destined to be landfilled. Each firm obtains revenues from selling its main product, whilst production costs are in the form of input purchasing cost and waste disposal cost.

The firms belong to several unrelated industries, each of them made up of a certain number of firms. We consider three industries: I1, I2 and I3. Feasible symbiotic relationships involving firms belonging to sequential industries exist. Accordingly, a generic firm belonging to the Industry I1 (I2, I3) can use as input the waste produced by any firm of the Industry I3 (I1, I2) and can send its waste to any firm of the Industry I2 (I3, I1), which uses it as a production input. For the sake of simplicity, we assume that each firm can send its waste only to one firm and can receive waste only from one firm. Firms' production processes and symbiotic relationships are modeled by adopting the Enterprise Input-Output approach $[48,75,76]$.

Each firm within the industrial network is modeled as an agent, who decides to establish or not a symbiotic relationship with another firm belonging to the feasible industry. A fitness function $F_{i \rightarrow j}$ $\left(F_{j \rightarrow i}\right)$ is defined, which measures the willingness of firm $i(j)$ to exchange wastes with firm $j(i)$. Such a fitness measure depends on two factors: (i) the economic benefits stemming from the IS relationship; and (ii) the path dependence. In the model, it is assumed that the higher the economic benefits that firm $i(j)$ could gain through the IS relationship with firm $j(i)$, the higher $F_{i \rightarrow j}\left(F_{j \rightarrow i}\right)$ will be. Moreover, path dependence is introduced by assuming that the longer the time firms $i$ and $j$ are involved in an effective resource exchange, the lower the importance of the economic benefit gained at time $t$ to motivate them to keep the symbiotic relationship [11]. Hence, the fitness function $F_{i \rightarrow j}$ at time $t$ is defined as follows:

$$
F_{i \rightarrow j}(t)=\frac{1}{L_{i j}(t)} \cdot E B_{i \rightarrow j}(t)+\left[1-\frac{1}{L_{i j}(t)}\right] \cdot E B_{i \rightarrow j}(t-1)
$$

where $L_{i j}(t)$ indicates the time length of the IS relationship between firms $i$ and $j$ at time $t$ and $E B_{i \rightarrow j}$ stands for the economic benefits that the firm $i$ gains from exchanging wastes with firm $j$. Such a benefit is defined as the ratio between the economic benefits stemming from IS and the firm's production costs:

$$
\begin{aligned}
& E B_{i \rightarrow j}(t)=\frac{d c_{i} \cdot e_{i \rightarrow j}(t)}{\left(p c_{i} \cdot R_{i}+d c_{i} \cdot W_{i}\right) \cdot x_{i}(t)} \\
& E B_{j \rightarrow i}(t)=\frac{p c_{j} \cdot e_{i \rightarrow j}(t)}{\left(p c_{j} \cdot R_{j}+d c_{j} \cdot W_{j}\right) \cdot x_{j}(t)}
\end{aligned}
$$

where $d c_{i}\left(d c_{j}\right)$ is the cost to dispose one unit of waste produced by firm $i(j), p c_{i}\left(p c_{j}\right)$ is the cost to purchase one unit of input required by firm $i(j), W_{i}\left(W_{j}\right)$ is the amount of waste generated by firm $i(j)$ to produce one unit of main product, $R_{i}\left(R_{j}\right)$ the amount of input required by firm $i$ to produce one unit of main product, $x_{i}(t)\left(x_{j}(t)\right)$ is the amount of main product produced by firm $i(j)$ at time $t$, and $e_{i \rightarrow j}(t)$ is the amount of waste exchanged between firms $i$ and $j$ at time $t$. Such a quantity is computed as follows, under the hypothesis that one waste unit perfectly replaces one input unit:

$$
e_{i \rightarrow j}(t)=\min \left\{W_{i} \cdot x_{i}(t) ; R_{j} \cdot x_{j}(t)\right\}
$$

For the sake of simplicity, we also assume that waste exchanges among firms are for free, i.e., that firms producing wastes do not pay any fee to firms using wastes and vice versa.

The firm $i$ decides to establish/maintain the symbiotic relationship with $j$ only if the fitness value associated with the symbiotic relationship is higher than or equal to a given threshold $\left(F_{i \rightarrow j} \geq T_{i}\right)$ [23]. 
This threshold models the firms' propensity to implement IS relationships. This propensity depends on the desired return on investment [3], which could include the additional costs associated with establishing IS relationships such as the transaction costs. The higher these costs, the higher the threshold value will be, ceteris paribus.

\subsection{The Agent-Based Model Dynamics}

The main goal of each agent is to improve its economic performance by adopting the IS practice. Let us consider the generic firm $i$ that was collaborating with firm $j$ at time $t-1$. At time $t$, both firms $i$ and $j$ compute their fitness by using Equation (1). The IS relationship is kept only if both fitness values are higher than or equal to the respective thresholds, otherwise it is interrupted. If the relationship is interrupted, firm $i$ seeks a firm with which to establish a new symbiotic relationship. Thus, it tries to establish a symbiotic relationship with firm $k$, randomly chosen. If firm $k$ is currently involved in a symbiotic relationship with firm $q$, firm $i$ remains with no link at time $t$. Alternatively, if firm $k$ is not currently involved in a symbiotic relationship, both firms compute their fitness values by using Equation (1). If both fitness values are higher than or equal to the respective thresholds, the relationship between $i$ and $k$ is created, otherwise both firms remain with no link at time $t$. Figure 1 shows the flow chart of the agent decision-making process. Such a process is repeated for a given number of time-periods (simulation time).

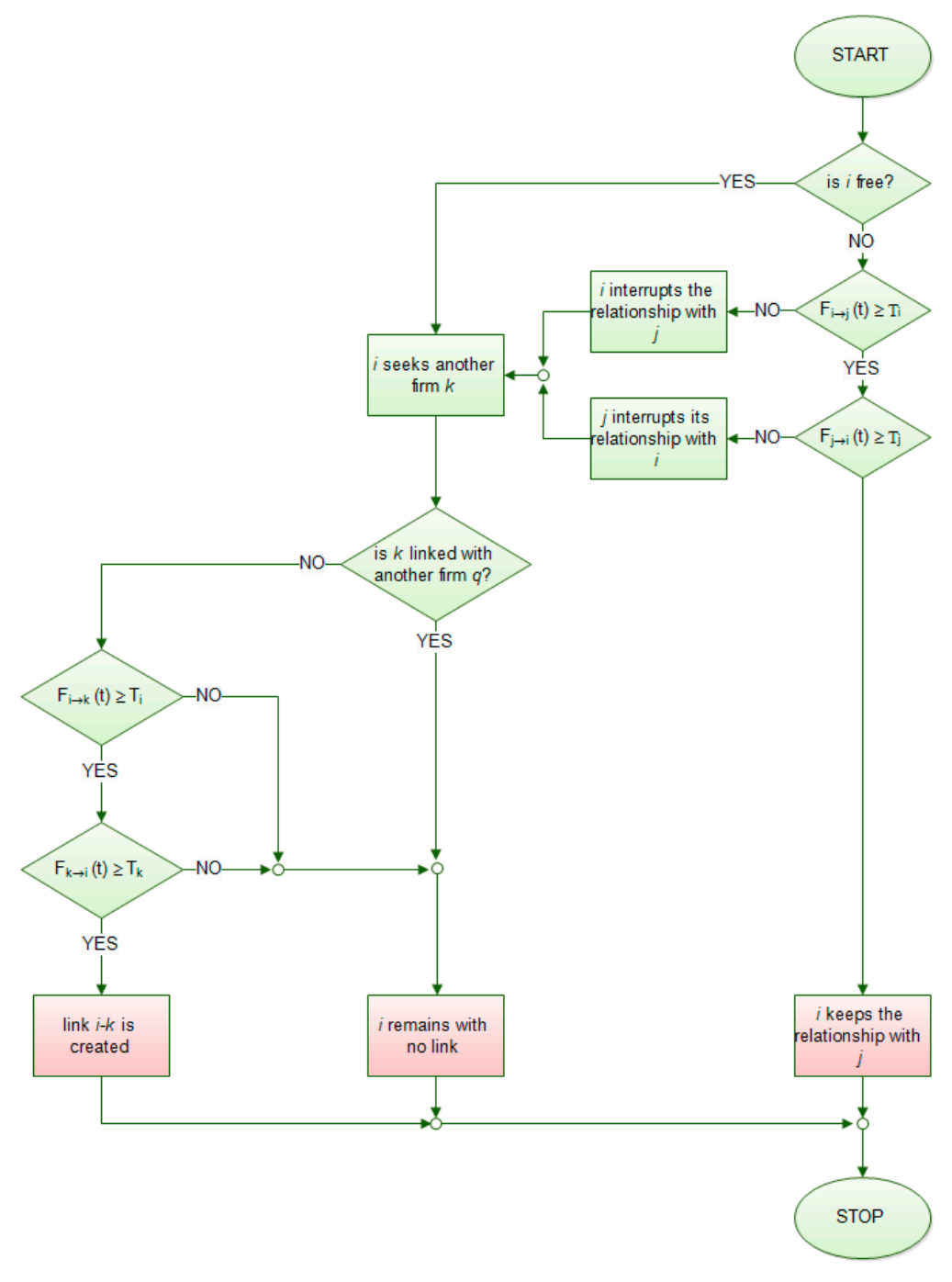

Figure 1. Flow chart of the agent decision-making process. 


\subsection{Policy Measures Investigated}

We consider two economic instruments and their effect on the emergence of the ISN: (i) the landfill tax; and (ii) the economic subsidies for IS transactions.

The first policy prescribes that firms pay the landfill tax for each unit of waste disposed of in the landfill. It results in increasing the waste disposal costs, ceteris paribus, so as to incentive firms to adopt the IS practice to reduce them. As effect of this policy, the economic benefit for firm $i$ stemming from the IS relationship with firm $j$ in presence of landfill $\operatorname{tax}\left(E B_{i \rightarrow j}^{L T}\right)$ is so modified:

$$
E B_{i \rightarrow j}^{L T}(t)=\frac{\left(d c_{i}+L T\right) \cdot e_{i \rightarrow j}(t)}{\left[\left(p c_{i} \cdot R_{i}+\left(d c_{i}+L T\right) \cdot W_{i}\right)\right] \cdot x_{i}(t)}
$$

where $L T$ is the landfill tax. Since $L T>0$ and $E B_{i \rightarrow j}(t)<1$, it can be easily demonstrated that $E B_{i \rightarrow j}^{L T}(t)>E B_{i \rightarrow j}(t)$, ceteris paribus.

This policy also generates monetary flows from firms to the government, thereby providing the government with additional revenues (GR), ceteris paribus. For the generic time $t$, the government revenues are:

$$
G R(t)=\sum_{a \in \mathrm{A}-\mathrm{B}} L T \cdot W_{a} \cdot x_{a}(t)+\sum_{b \in \mathrm{B}} L T \cdot\left[W_{b} \cdot x_{b}(t)-\sum_{c=1}^{N} e_{b \rightarrow c}(t)\right]
$$

where A stands for the set of total firms and B is the subset of firms implementing IS.

The economic subsidy policy prescribes that, for each unit of waste exchanged, the government pays the subsidy $S$ to both the firms involved. Such a measure improves the economic benefits for the firms implementing the IS practice, so pushing them to establish IS relationships. For firms $i$ and $j$ exchanging wastes, the economic benefits in presence of subsidy $\left(E B_{i \rightarrow j}^{S}\right.$ and $\left.E B_{j \rightarrow i}^{S}\right)$ are given by the following equations:

$$
\begin{aligned}
& E B_{i \rightarrow j}^{S}(t)=\frac{\left(d c_{i}+S\right) \cdot e_{i \rightarrow j}(t)}{\left(p c_{i} \cdot R_{i}+d c_{i} \cdot W_{i}\right) \cdot x_{i}(t)} \\
& E B_{j \rightarrow i}^{S}(t)=\frac{\left(p c_{j}+S\right) \cdot e_{i \rightarrow j}(t)}{\left(p c_{j} \cdot R_{j}+d c_{j} \cdot W_{j}\right) \cdot x_{j}(t)}
\end{aligned}
$$

where $E B_{i \rightarrow j}^{S}(t)>E B_{i \rightarrow j}(t)$ and $E B_{j \rightarrow i}^{S}(t)>E B_{j \rightarrow i}(t)$. Differently from the landfill tax policy, such a measure generates monetary flows from the government to firms, thereby determining expenses for the government $(G E)$. Such a monetary flow at time $t$ is computed as follows:

$$
G E(t)=2 \sum_{b \in \mathrm{B}} s \cdot \sum_{c=1}^{N} e_{b \rightarrow c}(t)
$$

Finally, we consider the case in which both policies are simultaneously adopted. In such a case, the net monetary flow (NF) is simply the sum of the revenues due to the landfill tax (Equation (6)) and the expenses due to the subsidy (Equation (9)):

$$
N F(t)=G R(t)-G E(t)=\sum_{a \in \mathrm{A}} L T \cdot W_{a} \cdot x_{a}(t)-\sum_{b \in \mathrm{B}}(L T+2 S) \cdot \sum_{c=1}^{N} e_{b \rightarrow c}(t)
$$

Such a monetary flow is from firms to the government when $N F(t)>0$ (i.e., when the government revenues are higher than the government expenses), otherwise is from the government to firms when $N F(t)<0$ (i.e., when the government revenues are lower than the government expenses).

The physical flows involving two generic firms establishing an IS relationship and the monetary flows between firms and government are shown in Figure 2 for all the three policy scenarios considered. 


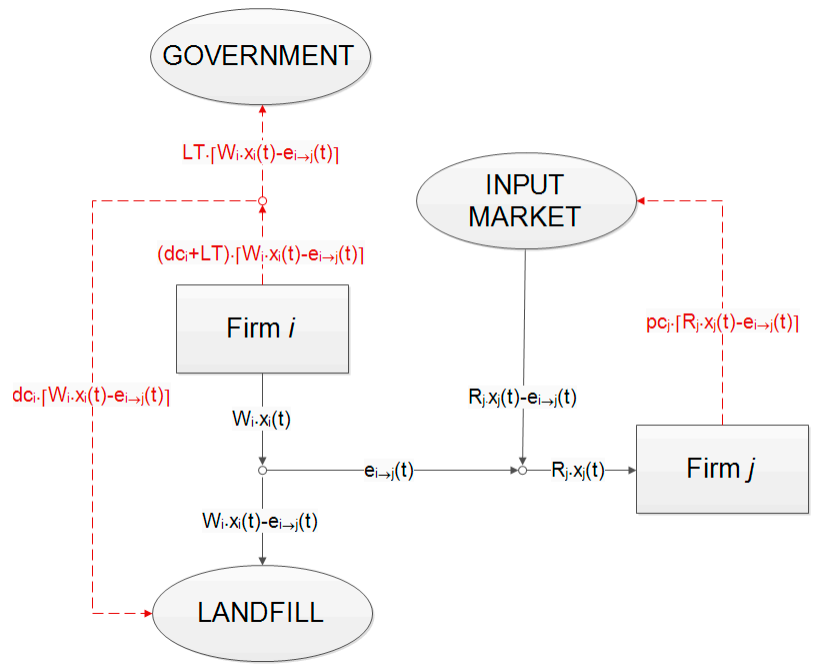

(a)

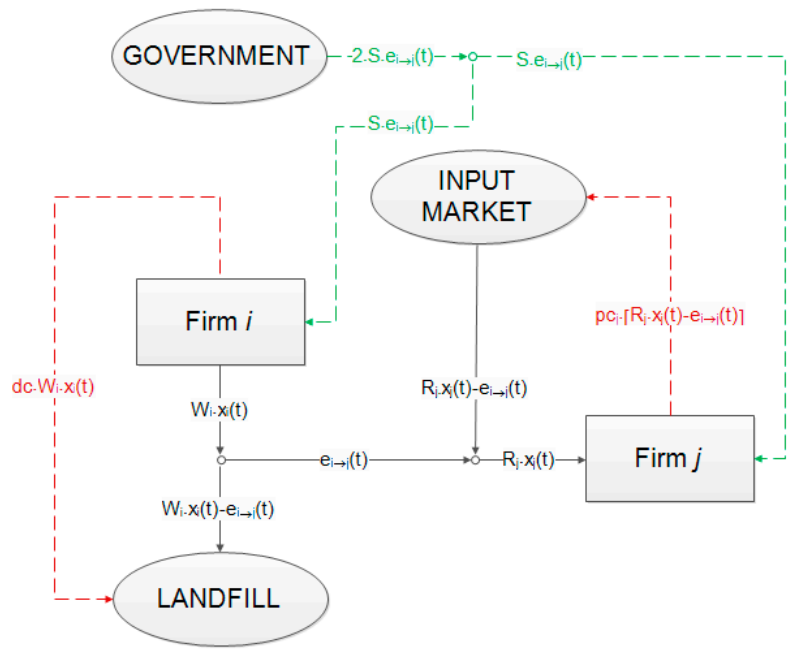

(b)

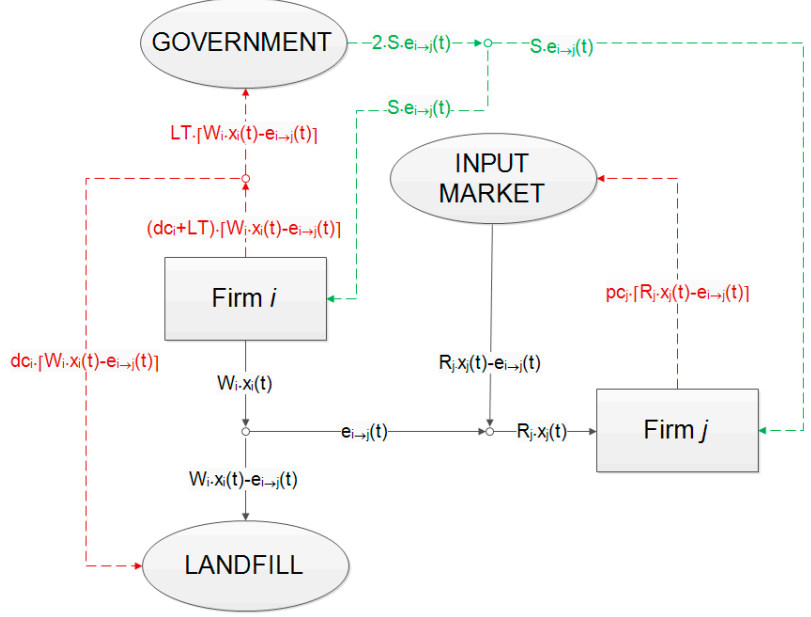

(c)

Figure 2. Physical flows between firms (continuous black lines) and monetary flows between firms and government (dotted red and green lines) in the case of: (a) landfill tax; (b) economic subsidy; (c) both policies. 


\subsection{Simulation Analysis}

To calibrate the simulation model, we use data referring to a real case study concerning a three-industry ISN discussed in the literature [77,78]. Table 1 shows main product generated, input required and waste produced by firms belonging to each industry.

Table 1. Data considered.

\begin{tabular}{cccc}
\hline Industry & Main Product & Input & Waste \\
\hline I1 & sugar & fertilizer & molasses \\
I2 & alcohol & molasses & alcohol slops \\
I3 & fertilizer & alcohol slops & waste fertilizer \\
\hline
\end{tabular}

We assume that 50 firms belong to each industry. Each firm observes a stochastic final customer demand over time, distributed according to a normal distribution with a given mean and variance. Numerical data on the main product demand, R, W, input purchasing cost and waste disposal cost are provided in Table 2.

Table 2. Main product demand, $\mathrm{R}$, input purchasing cost, $\mathrm{W}$ and waste disposal cost for firms belonging to each industry.

\begin{tabular}{cccccc}
\hline Industry & Main Product Average Demand & $\mathbf{R}$ & Input Purchasing Cost & $\mathbf{W}$ & Waste Disposal Cost \\
\hline I1 & $450,000 \mathrm{t} /$ year & 0.044 & $4000 € / \mathrm{t}$ & 0.2 & $90 € / \mathrm{t}$ \\
I2 & $25,000 \mathrm{t} /$ year & 4 & $80 € / \mathrm{t}$ & 0.8 & $90 € / \mathrm{t}$ \\
I3 & $30,000 \mathrm{t} /$ year & 0.4 & $70 € / \mathrm{t}$ & 0.1 & $90 € / \mathrm{t}$ \\
\hline
\end{tabular}

To analyze the efficacy of the policy measures, we define 16 scenarios by increasing the value of the landfill tax and the economic subsidy (Table 3 ). The value of both parameters is set as a percentage of increase of waste disposal cost $(0.1,0.2,0.3)$. This range of values guarantees the main effects of the policies on the emergence of IS relationships to be investigated. In particular, the scenario with no landfill tax and subsidy policy is defined as the base case. Three scenarios refer to the adoption of the landfill tax policy only, three scenarios to the use of the subsidy policy only, and nine scenarios to the simultaneous adoption of both policies. Each of the 16 scenarios is then simulated in different environments, characterized by four levels of environmental uncertainty and two levels of environmental turbulence (Table 4). These further simulations are performed to investigate the influence of the external environment on the efficacy of the policy measures.

Summarizing, the overall simulation plan consists of 128 different scenarios, resulting from 16 different combinations of policy values and 8 different environmental conditions.

Table 3. Parameters of the policy measures simulated.

\begin{tabular}{cc}
\hline Policy Measure & Values \\
\hline Landfill tax $(L T)$ & $0 € / \mathrm{t}, 9 € / \mathrm{t}, 18 € / \mathrm{t}, 27 € / \mathrm{t}$ \\
Economic subsidy $(S)$ & $0 € / \mathrm{t}, 9 € / \mathrm{t}, 18 € / \mathrm{t}, 27 € / \mathrm{t}$ \\
\hline
\end{tabular}

Table 4. Parameters of the environments.

\begin{tabular}{ccc}
\hline Variable & Modeling Variable & Values \\
\hline Environmental uncertainty $(E U)$ & Standard deviation of the main product demand & $0.1,0.2,0.3,0.4$ \\
Environmental turbulence $(E T)$ & Number of time periods the main product demand is fixed & 5,1 \\
\hline
\end{tabular}




\section{Results and Discussion}

We simulate each scenario for a simulation run of 1,000 periods and replicate 100 times so as to give statistical significance to results. At the end of simulation time, we compute the final number of total IS relationships in percentage to the total number of feasible relationships among firms. Then, such a number is averaged across all replications.

\subsection{Simulation Results}

Table 5 shows simulation results for the base case scenarios (i.e., absence of policy measures). Simulation results for scenarios characterized by the independent (simultaneous) adoption of landfill tax and subsidy policy are given in Table 6 (Table 7). For these scenarios defined by the values of the policy parameters ( $S$ and $L T$ ), we report the average percentage of IS relationships across all replications and the standard deviation in brackets in all the eight different environmental conditions. We also show the increase in the percentage of IS relationships compared to the base case $(\Delta \%)$. This value measures the efficacy of the policy in supporting the emergence of self-organized industrial symbiosis relationships. The higher the $\Delta \%$, the higher the efficacy of the policy.

Table 5. Number of industrial symbiosis (IS) relationships (in percentage) at the end of simulation time for the base scenario.

\begin{tabular}{ccccc}
\hline & $\boldsymbol{E U}=\mathbf{0 . 1}$ & $\boldsymbol{E U}=\mathbf{0 . 2}$ & $\boldsymbol{E U}=\mathbf{0 . 3}$ & $\boldsymbol{E U}=\mathbf{0 . 4}$ \\
\hline \multirow{2}{*}{ Low $\boldsymbol{E T}$} & 78.13 & 71.09 & 67.42 & 66.43 \\
& $(2.37)$ & $(2.88)$ & $(3.18)$ & $(2.96)$ \\
\hline \multirow{2}{*}{ High $\boldsymbol{E T}$} & 60.15 & 49.42 & 44.91 & 44.39 \\
& $(2.98)$ & $(3.39)$ & $(3.60)$ & $(3.64)$ \\
\hline
\end{tabular}

Standard deviation of the final number of symbiotic relations given in italics below the percentage value of IS relationships.

Table 6. Number of IS relationships (in percentage) at the end of simulation time for the scenarios characterized by the independent adoption of a single policy measure.

\begin{tabular}{|c|c|c|c|c|c|c|c|c|c|}
\hline \multicolumn{5}{|c|}{ Landfill Tax Policy } & \multicolumn{5}{|c|}{ Subsidy Policy } \\
\hline \multicolumn{5}{|c|}{$L T=9$} & \multicolumn{5}{|c|}{$S=9$} \\
\hline & $E U=0.1$ & $E U=0.2$ & $E U=0.3$ & $E U=0.4$ & & $E U=0.1$ & $E U=0.2$ & $E U=0.3$ & $E U=0.4$ \\
\hline \multirow[t]{2}{*}{ Low $E T$} & 85.75 & 75.92 & 71.43 & 67.44 & Low $E T$ & 87.47 & 76.98 & 72.57 & 68.39 \\
\hline & $(2.01)$ & (2.53) & $(2.80)$ & $(2.74)$ & & (1.98) & $(2.46)$ & (3.04) & (3.01) \\
\hline$\Delta \%$ & +9.74 & +6.79 & +5.94 & +1.53 & $\Delta \%$ & +11.95 & +8.28 & +7.63 & +2.96 \\
\hline \multirow[t]{2}{*}{ High $E T$} & 70.44 & 54.16 & 49.01 & 46.18 & High $E T$ & 72.92 & 55.88 & 48.95 & 47.07 \\
\hline & $(2.80)$ & $(3.91)$ & (3.19) & $(3.44)$ & & (3.16) & $(2.84)$ & $(3.40)$ & (3.15) \\
\hline \multirow[t]{3}{*}{$\Delta \%$} & +17.10 & +9.59 & +9.13 & +4.02 & $\Delta \%$ & +21.22 & +13.07 & +9.00 & +6.02 \\
\hline & \multicolumn{3}{|c|}{$L T=18$} & & \multicolumn{5}{|c|}{$S=18$} \\
\hline & $E U=0.1$ & $E U=0.2$ & $E U=0.3$ & $E U=0.4$ & & $E U=0.1$ & $E U=0.2$ & $E U=0.3$ & $E U=0.4$ \\
\hline Low ET & $\begin{array}{l}90.68 \\
(1.77)\end{array}$ & $\begin{array}{l}79.63 \\
(3.19)\end{array}$ & $\begin{array}{l}74.57 \\
(2.58)\end{array}$ & $\begin{array}{l}70.24 \\
(3.04)\end{array}$ & Low $E T$ & $\begin{array}{l}92.47 \\
(1.56)\end{array}$ & $\begin{array}{l}81.19 \\
(2.20)\end{array}$ & $\begin{array}{l}75.43 \\
(2.70)\end{array}$ & $\begin{array}{l}71.79 \\
(3.25)\end{array}$ \\
\hline$\Delta \%$ & +16.06 & +12.01 & +10.60 & +5.74 & $\Delta \%$ & +18.34 & +14.20 & +11.89 & +8.07 \\
\hline \multirow[t]{2}{*}{ High $E T$} & 79.28 & 59.48 & 52.77 & 49.34 & High $E T$ & 82.34 & 61.33 & 53.88 & 49.89 \\
\hline & $(2.36)$ & $(2.84)$ & $(4.07)$ & (3.69) & & $(2.50)$ & (3.44) & (3.87) & (3.28) \\
\hline \multirow[t]{3}{*}{$\Delta \%$} & +31.80 & +20.36 & +17.50 & +11.14 & $\Delta \%$ & +36.88 & +24.11 & +19.97 & +12.39 \\
\hline & & $L T=27$ & & & & & $S=27$ & & \\
\hline & $E U=0.1$ & $E U=0.2$ & $E U=0.3$ & $E U=0.4$ & & $E U=0.1$ & $E U=0.2$ & $E U=0.3$ & $E U=0.4$ \\
\hline Low $E T$ & $\begin{array}{l}93.78 \\
(1.34)\end{array}$ & $\begin{array}{l}82.33 \\
(2.76)\end{array}$ & $\begin{array}{l}76.70 \\
(2.82)\end{array}$ & $\begin{array}{l}72.55 \\
(3.09)\end{array}$ & Low $E T$ & $\begin{array}{l}95.57 \\
(1.30)\end{array}$ & $\begin{array}{l}84.61 \\
(2.22)\end{array}$ & $\begin{array}{l}78.27 \\
(2.55)\end{array}$ & $\begin{array}{l}73.59 \\
(2.61)\end{array}$ \\
\hline$\Delta \%$ & +20.03 & +15.81 & +13.76 & +9.21 & $\Delta \%$ & +22.31 & +19.01 & +16.10 & $\begin{array}{l}+10.78 \\
\end{array}$ \\
\hline \multirow[t]{2}{*}{ High $E T$} & 84.97 & 62.78 & 54.83 & 50.91 & High $E T$ & 88.93 & 66.60 & 57.31 & 51.93 \\
\hline & $(2.24)$ & (3.35) & (3.49) & $(4.20)$ & & (1.86) & (3.37) & (3.16) & (4.03) \\
\hline$\Delta \%$ & +41.26 & +27.03 & +22.09 & +14.67 & $\Delta \%$ & +47.84 & +34.76 & +27.59 & +16.98 \\
\hline
\end{tabular}

Standard deviation of the final number of symbiotic relations given in italics below the percentage value of IS relationships; $\Delta \%=$ increase in the number of symbiotic relations compared to the base case scenario. 
Table 7. Number of IS relationships (in percentage) at the end of simulation time for the scenarios characterized by the simultaneous adoption of landfill tax and subsidy policies.

\begin{tabular}{|c|c|c|c|c|c|c|c|c|c|}
\hline \multicolumn{5}{|c|}{$S=9 L T=9$} & \multicolumn{5}{|c|}{$S=9 L T=18$} \\
\hline & $E U=0.1$ & $E U=0.2$ & $E U=0.3$ & $E U=0.4$ & & $E U=0.1$ & $E U=0.2$ & $E U=0.3$ & $E U=0.4$ \\
\hline Low $E T$ & 91.82 & $\begin{array}{l}80.09 \\
(2.46)\end{array}$ & 74.07 & 70.82 & Low $E T$ & 94.08 & 83.23 & $\begin{array}{l}76.71 \\
(288)\end{array}$ & 72.88 \\
\hline$\Delta \%$ & $\begin{array}{l}17.52 \\
+17.52\end{array}$ & +12.65 & +9.87 & +6.61 & $\Delta \%$ & +20.41 & +17.08 & $\begin{array}{r}2.007 \\
+13.78\end{array}$ & $\begin{array}{r}+9.71 \\
+\end{array}$ \\
\hline \multirow{2}{*}{ High $E T$} & 80.22 & 59.15 & 52.49 & 48.89 & \multirow{2}{*}{ High ET } & 86.30 & 64.09 & 56.01 & 50.85 \\
\hline & $(2.29)$ & $(3.20)$ & $(3.78)$ & $(3.54)$ & & (2.19) & $(3.58)$ & $(3.27)$ & $(3.65)$ \\
\hline \multirow[t]{3}{*}{$\Delta \%$} & +33.36 & +19.70 & +16.88 & +10.14 & $\Delta \%$ & +43.47 & +29.68 & +24.70 & +14.55 \\
\hline & \multicolumn{3}{|c|}{$S=9 L T=27$} & & \multicolumn{5}{|c|}{$S=18 L T=9$} \\
\hline & $E U=0.1$ & $E U=0.2$ & $E U=0.3$ & $E U=0.4$ & & $E U=0.1$ & $E U=0.2$ & $E U=0.3$ & $E U=0.4$ \\
\hline \multirow[t]{2}{*}{ Low $E T$} & 95.73 & 84.72 & 79.03 & 73.72 & \multirow[t]{2}{*}{ Low $E T$} & 95.11 & 83.55 & 77.23 & 73.61 \\
\hline & (1.26) & $(2.46)$ & $(2.37)$ & (3.17) & & (1.43) & (2.09) & $(2.77)$ & $(2.81)$ \\
\hline$\Delta \%$ & +22.53 & +19.17 & +17.22 & +10.98 & $\Delta \%$ & +21.73 & +17.52 & +14.55 & +10.82 \\
\hline \multirow[t]{2}{*}{ High $E T$} & 90.08 & 67.60 & 58.51 & 53.23 & \multirow[t]{2}{*}{ High $E T$} & 87.67 & 64.99 & 56.01 & 51.54 \\
\hline & (1.95) & (3.85) & (3.75) & (3.24) & & (2.11) & (2.79) & (3.83) & (3.39) \\
\hline \multirow[t]{3}{*}{$\Delta \%$} & +49.75 & +36.79 & +30.28 & +19.90 & $\Delta \%$ & +45.75 & +31.50 & +24.71 & +16.10 \\
\hline & \multicolumn{3}{|c|}{$S=18 L T=18$} & & \multicolumn{5}{|c|}{$S=18 L T=27$} \\
\hline & $E U=0.1$ & $E U=0.2$ & $E U=0.3$ & $E U=0.4$ & & $E U=0.1$ & $E U=0.2$ & $E U=0.3$ & $E U=0.4$ \\
\hline \multirow[t]{2}{*}{ Low $E T$} & 96.08 & 85.87 & 78.62 & 74.51 & \multirow[t]{2}{*}{ Low $E T$} & 97.35 & 86.86 & 80.84 & 75.62 \\
\hline & (1.26) & (2.39) & $(2.48)$ & $(2.90)$ & & (1.01) & $(2.10)$ & $(2.60)$ & $(2.63)$ \\
\hline$\Delta \%$ & +22.97 & +20.78 & +16.62 & +12.17 & $\Delta \%$ & +24.60 & +22.18 & +19.91 & +13.84 \\
\hline \multirow[t]{2}{*}{ High $E T$} & 90.86 & 68.63 & 59.29 & 53.65 & \multirow[t]{2}{*}{ High $E T$} & 92.36 & 71.37 & 60.21 & 54.43 \\
\hline & (1.84) & (3.45) & (3.65) & $(3.40)$ & & (1.32) & (3.31) & (3.73) & (3.85) \\
\hline \multirow[t]{3}{*}{$\Delta \%$} & +51.05 & +38.87 & +32.01 & +20.86 & $\Delta \%$ & +53.54 & +44.41 & +34.05 & +22.62 \\
\hline & \multicolumn{3}{|c|}{$S=27 L T=9$} & & \multicolumn{5}{|c|}{$S=27 L T=18$} \\
\hline & $E U=0.1$ & $E U=0.2$ & $E U=0.3$ & $E U=0.4$ & & $E U=0.1$ & $E U=0.2$ & $E U=0.3$ & $E U=0.4$ \\
\hline \multirow[t]{2}{*}{ Low $E T$} & 96.51 & 86.22 & 79.57 & 75.11 & \multirow[t]{2}{*}{ Low $E T$} & 97.37 & 87.35 & 80.56 & 76.51 \\
\hline & (1.32) & (2.13) & $(2.82)$ & $(2.75)$ & & (1.02) & (1.95) & $(2.60)$ & $(2.74)$ \\
\hline$\Delta \%$ & +23.52 & +21.28 & +18.02 & +13.08 & $\Delta \%$ & +24.62 & +22.87 & +19.49 & +15.18 \\
\hline High $E T$ & 91.89 & 69.99 & 58.96 & 54.66 & High ET & 93.28 & 71.85 & 61.25 & 55.56 \\
\hline & $(1.70)$ & $(2.98)$ & $(3.83)$ & $(3.34)$ & & (1.59) & (3.06) & $(3.24)$ & (3.63) \\
\hline$\Delta \%$ & +52.75 & +41.62 & +31.28 & +23.13 & $\Delta \%$ & +55.07 & +45.39 & +36.37 & +25.15 \\
\hline & & $=27 L T=2$ & & & & & & & \\
\hline & $E U=0.1$ & $E U=0.2$ & $E U=0.3$ & $E U=0.4$ & & & & & \\
\hline Low $E T$ & 97.69 & 88.11 & 82.15 & 76.76 & & & & & \\
\hline & $(0.80)$ & (1.87) & $(2.40)$ & $(2.74)$ & & & & & \\
\hline$\Delta \%$ & +25.03 & +23.94 & +21.85 & +15.55 & & & & & \\
\hline High $E T$ & 94.01 & 73.48 & 63.12 & 57.19 & & & & & \\
\hline & (1.51) & (3.05) & (3.90) & $(3.76)$ & & & & & \\
\hline$\Delta \%$ & +56.28 & +48.69 & +40.53 & +28.83 & & & & & \\
\hline
\end{tabular}

Standard deviation of the final number of symbiotic relations given in italics below the percentage value of IS relationships; $\Delta \%=$ increase in the number of symbiotic relations compared to the base case scenario.

First, we note that in all scenarios both uncertainty and turbulence have a negative effect on the emergence of ISNs. This trend is expected because it is coherent with both empirical observations and previous contributions of the literature $[28,32,51]$ and confirms the internal validity of the simulation model, able to reproduce expected results. Then, we analyze the effect of the policy measures in supporting the emergence of IS relationships.

We find that in all the scenarios simulated there is an increase of the number of IS relationships thanks to the adoption of the policies compared to the base scenario, regardless of the environmental conditions. In particular, depending on the environmental conditions and the value of policy parameters, the increase in the number of IS relationships ranges from 1.53\% to $41.26 \%$ in the case of landfill tax policy, from $2.96 \%$ to $47.84 \%$ in the case of subsidy policy, and from $6.61 \%$ to $56.28 \%$ in the case of the simultaneous adoption of both measures. Note that, although the simultaneous adoption of both policy measures is favorable in terms of the emergence of IS relationships (i.e., higher increase), the combined effect of tax and subsidy is lower than the sum of the single effects. For example, in the case of $E U=0.1$ and low $E T$ the adoption of landfill tax policy with $L T=9 € / \mathrm{t}$ determines an increase in the number of IS relationships equal to $9.74 \%$, the adoption of the economic subsidy policy with 
$S=9 € / \mathrm{t}$ achieves an increase of $11.95 \%$, but their simultaneous adoption causes an increase of only $17.52 \%(<21.64 \%=9.74 \%+11.95 \%)$.

Our results also show that increasing the landfill tax and subsidy value positively influences the emergence of IS relationships. This is an expected result because both policies incentivize firms to establish IS relationships so as to increase their economic benefits. However, we find that there is an effect of decreasing returns, which is less intuitive. For example, consider the scenario with $E U=0.1$ and high $E T$. For the landfill tax policy, $L T$ rising from $9 € / \mathrm{t}$ to $18 € / \mathrm{t}$ makes an increase of $14.7 \%$ in the percentage of IS relationships, $L T$ rising from $18 € / t$ to $27 € / t$ determines an improvement of $9.46 \%$. Similarly, for the subsidy policy, $S$ moving from $9 € / \mathrm{t}$ to $18 € / \mathrm{t}$ improves the number of IS relationships of $15.66 \%$, while from $18 € / \mathrm{t}$ to $27 € / \mathrm{t}$ of only $10.96 \%$. Figure 3 depicts the number of IS relationships for different values of economic subsidy and landfill tax for the scenario characterized by $E U=0.1$ and low ET. It clearly shows this trend.

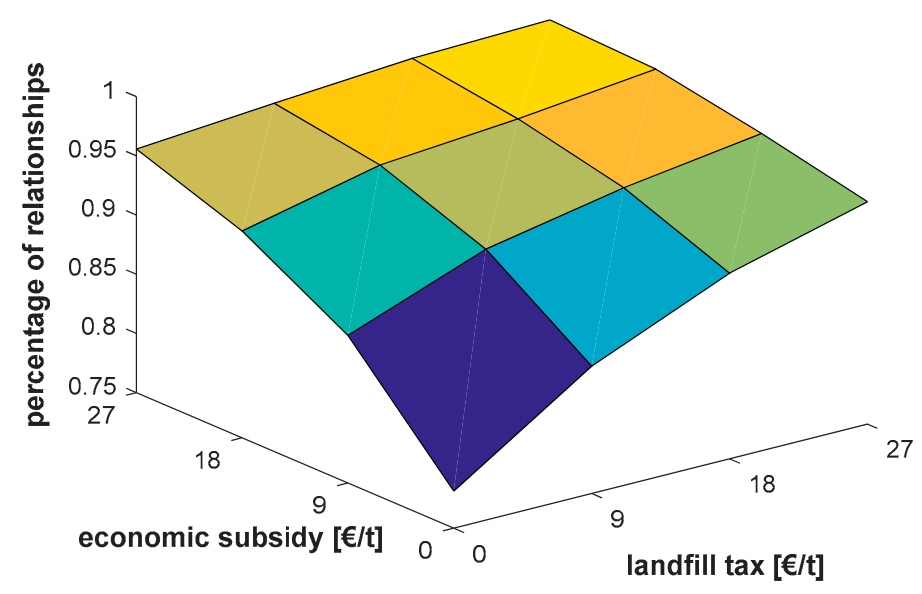

Figure 3. Number of IS relationships (in percentage) for different levels of economic subsidy and landfill tax values $(E U=0.1$ and Low $E T)$.

The influence of the environmental conditions on the emergence of IS relationships also deserves some comments. Results show that both the environmental uncertainty and the environmental turbulence influence the efficacy of the policy measures to support the emergence of IS relationships. In particular, the highest increase of the number of IS relationships is achieved in the scenarios characterized by high turbulence as well as in scenarios with low uncertainty. Ceteris paribus, the higher the environmental turbulence, the higher the efficacy of the policy measures will be. Similarly, the higher the environmental uncertainty, the lower the efficacy of the policy measures will be, ceteris paribus. This outcome emphasizes that proper policy measure should be designed depending on the environmental conditions.

Generally, ISNs are observed to arise in environments characterized by low turbulence low and uncertainty. On the one hand, high-turbulent environments require firms to be flexible and to adapt quickly to the new external conditions by rapidly adding new partners [79,80]. However, IS exchanges are constrained by both technical features and geographical proximity among firms; therefore, the number of new symbiotic partners is often limited. In this regard, our results are interesting because they show that the increase in economic benefits due to appropriate policy measures ensures that IS relationships are enough convenient for firms, even in more turbulent environments. On the other hand, uncertainty deteriorates the economic and environmental performance of firms involved in IS relationships [32], discouraging them from establishing long-term relationships. Despite the policy measures increasing the economic benefits for firms, they do not reduce the negative effect of uncertainty on these benefits. Therefore, the policy measures have low efficacy in high-uncertainty environments. 
Finally, we use simulation data to build the curves showing the combination of tax and subsidy values determining the same increase of IS relationships, compared to the base case scenario (iso-effect curve). As an example, Figure 4 shows the iso-effect curves for $E U=0.1$ and low $E T$.

These curves are a tool to provide information to policy makers quickly on the benefits associated with the policy measures, depending on the parameters values. They can be used to set the value of $L T$ and/or $S$ so as to obtain a given number of IS relationships.

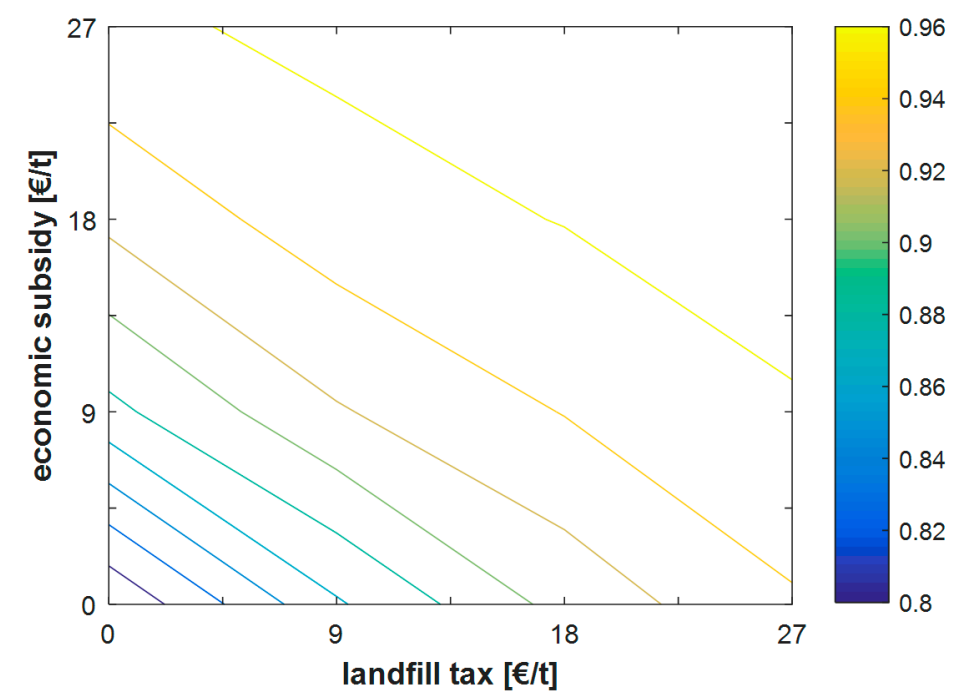

Figure 4. "Iso-effect" curves for the scenario characterized by $E U=0.1$ and low $E T$.

\subsection{Monetary Flows Generated by Policy Measures}

In this section, we compute the monetary flows generated by the policy measures. In particular, a landfill tax policy generates monetary flows from firms to the government (the amount of these flows can be computed by Equation (6)), whilst the use of economic subsidies generates monetary flows from the government to firms (Equation (9)). In the case of the simultaneous adoption of both tax and subsidy, the direction of monetary flows is uncertain, depending on the net effect of such a simultaneous adoption (Equation (10)). In performing this analysis, we do not take into account the additional costs that the government should pay for policy implementation. The quantification of these costs is important in order to compute the net benefit of the policy measures for the government. For example, the economic subsidy policy requires that the government monitors the effective exchange of wastes between the firms involved in the symbiotic relationship. The landfill tax policy should be less costly than the economic subsidy from this point of view, but it could generate additional monitoring cost for the government, because it may induce firms to adopt unfair practice such as illegal dumping [81]. This analysis is however out of the paper's scope.

Results are shown in Table 8. Note that the revenue associated with a landfill tax policy grows less than proportionally to the landfill tax. For example, consider the environmental scenario characterized by $E U=0.1$ and low $E T$. By imposing a landfill tax equal to $10 \%$ of waste disposal cost $(L T=9 € / t)$, the government obtains a revenue of 11.43 million $€$. However, by doubling the landfill $\operatorname{tax}(L T=18 € / \mathrm{t})$, the revenues only grow to 20.26 million $€$ (i.e., less than double). This phenomenon happens because the increase of landfill tax value pushes the companies more and more to adopt IS practice, thereby decreasing the amount of waste disposed of in the landfill. Therefore, what firms pay due to the landfill tax diminishes.

However, the expense due to the subsidy policy rises more than proportionally to the economic subsidy, irrespective of environmental uncertainty and turbulence. Consider again the environmental scenario characterized by $E U=0.1$ and low $E T$. By providing subsidy equal to $9 € / t$, the government expense is 83.33 million $€$, but increasing the subsidy to $18 € / \mathrm{t}$ makes the expense grow to 184.14 
million $€$ (i.e., more than the double). This occurs because when the subsidy value is increased, two conditions raise the expenses for the government: (i) more firms implement IS practice; and (ii) each firm implementing IS practice receives a higher amount of money because of higher $S$.

Finally, we analyze the results concerning the simultaneous adoption of landfill tax and economic subsidy. As we expected, the results of these scenarios show that increasing tax value is beneficial for the government because it reduces the negative net flow. In this regard, however, we find a surprising result that could be interesting for policy makers, because it is counterintuitive. In some conditions (low environmental uncertainty) and, for given subsidy values $(S=18 € / \mathrm{t}$ and $27 € / \mathrm{t}$ ), increasing the landfill tax has a negative effect on the net flow for the government. This happens because the higher value of the landfill tax increases the revenues for the government but, since at the same time it pushes more firms to adopt IS practice, determines an increase of the expenses higher than the improvement of revenue.

Table 8. Overall net flow for the government in all scenarios. Data are in $10^{6} €$.

\begin{tabular}{|c|c|c|c|c|c|c|}
\hline \multicolumn{2}{|c|}{ Scenario } & & $E U=0.1$ & \multirow{2}{*}{$\begin{array}{c}E \boldsymbol{E}=\mathbf{0 . 2} \\
16.50\end{array}$} & \multirow{2}{*}{$\begin{array}{c}E \boldsymbol{E}=\mathbf{0 . 3} \\
18.13\end{array}$} & \multirow{3}{*}{$\begin{array}{c}\boldsymbol{E} \boldsymbol{U}=\mathbf{0 . 4} \\
20.21 \\
34.21\end{array}$} \\
\hline & & Low ET & 11.43 & & & \\
\hline$S=0$ & $L T=9$ & High $E T$ & 25.21 & 31.12 & 33.06 & \\
\hline \multirow{2}{*}{$S=0$} & \multirow{2}{*}{$L T=18$} & Low $E T$ & 20.26 & 31.38 & 36.99 & 40.74 \\
\hline & & High $E T$ & 35.27 & 54.44 & 60.53 & 63.84 \\
\hline \multirow{2}{*}{$S=0$} & \multirow{2}{*}{$L T=27$} & Low $E T$ & 22.55 & 41.12 & 49.39 & 56.18 \\
\hline & & High ET & 37.54 & 72.86 & 84.74 & 91.37 \\
\hline \multirow{2}{*}{$S=9$} & \multirow{2}{*}{$L T=0$} & Low $E T$ & -83.33 & -73.26 & -69.75 & -65.32 \\
\hline & & High $E T$ & -61.20 & -48.39 & -43.96 & -42.76 \\
\hline \multirow{2}{*}{$S=18$} & \multirow{2}{*}{$L T=0$} & Low $E T$ & -184.14 & -159.16 & -148.63 & -141.37 \\
\hline & & High $E T$ & -155.85 & -114.46 & -100.81 & -93.42 \\
\hline \multirow{2}{*}{$S=27$} & \multirow{2}{*}{$L T=0$} & Low $E T$ & -290.58 & -255.11 & -234.78 & -218.87 \\
\hline & & High $E T$ & -264.82 & -195.94 & -165.53 & -149.64 \\
\hline \multirow{2}{*}{$S=9$} & \multirow{2}{*}{$L T=9$} & Low $E T$ & -81.34 & -63.08 & -53.69 & -48.90 \\
\hline & & High $E T$ & -58.34 & -28.49 & -19.14 & -14.85 \\
\hline \multirow{2}{*}{$S=9$} & \multirow{2}{*}{$L T=18$} & Low $E T$ & -80.89 & -57.99 & -45.46 & -35.24 \\
\hline & & High ET & -62.45 & -16.20 & -0.08 & 13.33 \\
\hline \multirow{2}{*}{$S=9$} & \multirow{2}{*}{$L T=27$} & Low $E T$ & -81.64 & -52.63 & -36.58 & -22.25 \\
\hline & & High $E T$ & -66.84 & -8.03 & 17.24 & 33.44 \\
\hline \multirow[b]{2}{*}{$S=18$} & \multirow[b]{2}{*}{$L T=9$} & Low $E T$ & -185.32 & -154.61 & -138.98 & -130.88 \\
\hline & & High $E T$ & -163.23 & -102.75 & -77.93 & -66.13 \\
\hline \multirow[b]{2}{*}{$S=18$} & \multirow[b]{2}{*}{$L T=18$} & Low $E T$ & -186.97 & -152.08 & -131.80 & -116.11 \\
\hline & & High $E T$ & -171.33 & -97.26 & -66.64 & -47.88 \\
\hline \multirow[b]{2}{*}{$S=18$} & \multirow[b]{2}{*}{$L T=27$} & Low ET & -188.07 & -151.68 & -128.50 & -107.29 \\
\hline & & High $E T$ & -178.03 & -96.27 & -52.45 & -25.23 \\
\hline \multirow{2}{*}{$S=27$} & \multirow{2}{*}{$L T=9$} & Low $E T$ & -291.50 & -253.83 & -230.86 & -210.27 \\
\hline & & High $E T$ & -275.75 & -191.86 & -150.45 & -130.99 \\
\hline \multirow{2}{*}{$S=27$} & & Low ET & -292.95 & -251.21 & -223.47 & -207.87 \\
\hline & $L T=18$ & High $E T$ & -282.11 & -190.05 & -139.11 & -111.61 \\
\hline & & Low $E T$ & -293.99 & -250.80 & -220.50 & -193.29 \\
\hline$S=27$ & $L T$ & High ET & -285.68 & -187.83 & -132.05 & -100.97 \\
\hline
\end{tabular}

\section{Conclusions}

Despite empirical cases demonstrate that IS practice can be stimulated by governmental policy actions, the extent to which policy measures can contribute to the spontaneous emergence of ISNs is 
a matter that needs further investigation in the literature. This paper offers a contribution in filling this gap.

We developed a simulation model to carry out a simulation analysis aimed at investigating the efficacy of two policy measures-landfill tax and economic subsidy to IS transactions-as a way to foster the emergence of self-organized ISNs in different scenarios, characterized by increasing levels of uncertainty and turbulence of the external environment.

The simulation analysis confirmed that the policy measures have a positive effect on the emergence of ISNs, both singularly and simultaneously implemented. While the positive effect of economic subsidy is more to be expected-since it is reasonable to suppose that firms would not dispose their wastes of in the landfill if they are paid to adopt IS practice-the effect of landfill tax is less intuitive. In fact, a few studies highlighted the positive correlation between the increase in the landfill tax and the reduction in the amount of wastes landfilled [82-87], but other studies found landfill a not-significant driver for landfill diversion [88]. Our results showed that, forced by higher waste disposal costs, firms are willing to create IS relationships rather than to dispose waste in the landfill.

However, we found that the magnitude of the effect of policy measures is strongly influenced by the environmental scenario in which IS transactions are implemented. This issue provides a theoretical justification to empirical observations showing that the impact of policy measures may differ depending on the specific case analyzed.

Furthermore, our results provide interesting implications for policy makers. We showed how to achieve a desired effect in terms of improvement of IS relationships by fine-tuning the policy parameters. We also quantified monetary flows from firms to the government and vice versa, generated by the adoption of the policy measures. Together, these results suggest that by fine-tuning the policy parameters, policy makers can design the level of IS relationships to promote. In addition, our study provides a methodological advance in the study of the self-organized IS approach since, to the best of our knowledge, no previous studies adopted the agent-based simulation approach to study this issue.

Finally, our study presents a few limits. Firstly, results are context-specific and require further investigation to be validated in further situations. Moreover, our model is based on some simplifying assumptions: (i) each firm can be involved in no more than two IS relationships contemporaneously (the former with the firm receiving its waste, the latter with the firm sending the waste it produces); (ii) firm transaction costs are not directly taken into account; (iii) waste treatment and waste transportation costs are considered negligible; and (iv) social attributes characterizing firm relationships are not included.

Further developments will be focused on modeling improvements to overcome the limitations above. In particular, we will introduce the possibility for each firm to establish more than one relationship both upstream and downstream and the firms' transaction costs. A further improvement of the model will concern the development of a "government" agent and the definition of the attendant actions and goals. In such a way, the model would be able to consider the additional costs for the government due to policy implementation. This would allow the net benefit of each policy measure to be quantified and different policies to be compared from the economic point of view, in order to identify the best policy to adopt in each environmental condition.

Acknowledgments: This work was supported by Camera di Commercio, Industria, Artigianato e Agricoltura di Bari [Chamber of Commerce, Industry, Crafts, and Agriculture of Bari] (project "Borsa delle idee"). The authors would like to thank the reviewers for their valuable comments.

Author Contributions: All authors contributed to the concept and design of the research. Luca Fraccascia and Ilaria Giannoccaro designed the agent-based model. Luca Fraccascia performed the simulations and analyzed data. Luca Fraccascia and Ilaria Giannoccaro discussed the results. Finally, Ilaria Giannoccaro and Vito Albino developed policy implications and conclusions.

Conflicts of Interest: The authors declare no conflict of interest. 


\section{References}

1. Chertow, M.R. Industrial Symbiosis: Literature and Taxonomy. Annu. Rev. Energy Environ. 2000, 25, 313-337. [CrossRef]

2. Fraccascia, L.; Magno, M.; Albino, V. Business models for industrial symbiosis: A guide for firms. Procedia Environ. Sci. Eng. Manag. 2016, 3, 83-93.

3. Mirata, M. Experiences from early stages of a national industrial symbiosis programme in the UK: Determinants and coordination challenges. J. Clean. Prod. 2004, 12, 967-983. [CrossRef]

4. Esty, D.C.; Porter, M.E. Industrial Ecology and Competitiveness. J. Ind. Ecol. 1998, 2, 35-43. [CrossRef]

5. Albino, V.; Fraccascia, L.; Savino, T. Industrial Symbiosis for a Sustainable City: Technical, Economical and Organizational Issues. Procedia Eng. 2015, 118, 950-957. [CrossRef]

6. Wang, H.; Xu, X.; Zhu, G. Landscape Changes and a Salt Production Sustainable Approach in the State of Salt Pan Area Decreasing on the Coast of Tianjin, China. Sustainability 2015, 7, 10078-10097. [CrossRef]

7. European Commission. Roadmap to a Resource Efficient Europe; European Commission: Bruxelles, Belgium, 2011.

8. European Commission. Closing the Loop-An EU action plan for the Circular Economy; European Commission: Bruxelles, Belgium, 2015.

9. Fichtner, W.; Tietze-Stöckinger, I.; Frank, M.; Rentz, O. Barriers of interorganisational environmental management: Two case studies on industrial symbiosis. Prog. Ind. Ecol. Int. J. 2005, 2, 73-88. [CrossRef]

10. Hage, J.; Alter, C. A Typology of interorganizational relationships and networks. In Contemporary Capitalism: The Embeddedness of Institutions; Rogers Hollingsworth, J., Boyer, R., Eds.; Cambridge University Press: New York, NY, USA, 1997; pp. 94-126.

11. Chertow, M.R. “Uncovering” Industrial Symbiosis. J. Ind. Ecol. 2007, 11, 11-30. [CrossRef]

12. Doménech, T.; Davies, M. The role of Embeddedness in Industrial Symbiosis Networks: Phases in the Evolution of Industrial Symbiosis Networks. Bus. Strategy Environ. 2011, 20, 281-296. [CrossRef]

13. Jacobsen, N.B. Industrial Symbiosis in Kalundborg, Denmark: A Quantitative Assessment of Economic and Environmental Aspects. J. Ind. Ecol. 2006, 10, 239-255. [CrossRef]

14. Garner, A.; Keoleian, G.A. Industrial Ecology: An Introduction; University of Michigan: Ann Arbor, MI, USA, 1995.

15. Tudor, T.; Adam, E.; Bates, M. Drivers and limitations for the successful development and functioning of EIPs (eco-industrial parks): A literature review. Ecol. Econ. 2007, 61, 199-207. [CrossRef]

16. Fraccascia, L.; Giannoccaro, I.; Albino, V. Rethinking Resilience in Industrial Symbiosis: Conceptualization and measurements. Ecol. Econ. 2017, 137, 148-162. [CrossRef]

17. Paquin, R.L.; Busch, T.; Tilleman, S.G. Creating Economic and Environmental Value through Industrial Symbiosis. Long Range Plan. 2015, 48, 95-107. [CrossRef]

18. Costa, I.; Ferrão, P. A case study of industrial symbiosis development using a middle-out approach. J. Clean. Prod. 2010, 18, 984-992. [CrossRef]

19. Gibbs, D.; Deutz, P. Reflections on implementing industrial ecology through eco-industrial park development. J. Clean. Prod. 2007, 15, 1683-1695. [CrossRef]

20. Costa, I.; Massard, G.; Agarwal, A. Waste management policies for industrial symbiosis development: Case studies in European countries. J. Clean. Prod. 2010, 18, 815-822. [CrossRef]

21. Boons, F.; Chertow, M.; Park, J.; Spekkink, W.; Shi, H. Industrial Symbiosis Dynamics and the Problem of Equivalence: Proposal for a Comparative Framework. J. Ind. Ecol. 2016. [CrossRef]

22. Ohnishi, S.; Fujita, T.; Chen, X.; Fujii, M. Econometric analysis of the performance of recycling projects in Japanese Eco-Towns. J. Clean. Prod. 2012, 33, 217-225. [CrossRef]

23. Shi, H.; Chertow, M.; Song, Y. Developing country experience with eco-industrial parks: A case study of the Tianjin Economic-Technological Development Area in China. J. Clean. Prod. 2010, 18, 191-199. [CrossRef]

24. Behera, S.K.; Kim, J.-H.; Lee, S.-Y.; Suh, S.; Park, H.-S. Evolution of “designed” industrial symbiosis networks in the Ulsan Eco-industrial Park: "Research and development into business" as the enabling framework. J. Clean. Prod. 2012, 29, 103-112. [CrossRef]

25. Jiao, W.; Boons, F. Toward a research agenda for policy intervention and facilitation to enhance industrial symbiosis based on a comprehensive literature review. J. Clean. Prod. 2014, 67, 14-25. [CrossRef] 
26. Chertow, M.R. Dynamics of geographically based industrial ecosystems. In The Dynamics of Regions and Networks in Industrial Ecosystems; Ruth, M., Davidsdottir, B., Eds.; Edward Elgar: Cheltenham, UK; Northampton, MA, USA, 2009.

27. Chertow, M.R.; Ehrenfeld, J. Organizing Self-Organizing Systems. J. Ind. Ecol. 2012, 16, 13-27. [CrossRef]

28. Albino, V.; Fraccascia, L.; Giannoccaro, I. Exploring the role of contracts to support the emergence of self-organized industrial symbiosis networks: An agent-based simulation study. J. Clean. Prod. 2016, 112, 4353-4366. [CrossRef]

29. Dooley, K.J. A Complex Adaptive Systems Model of Organization Change. Nonlinear Dyn. Psychol. Life Sci. 1997, 1, 69-97. [CrossRef]

30. Holland, J.H. Hidden Order: How Adaptation Builds Complexity; Addison-Wesley: Reading, MA, USA, 1995.

31. Holland, J.H. Complex Adaptive Systems and Spontaneous Emergence. In Complexity and Industrial Clusters; Quadro Curzio, A., Fortis, M., Eds.; Physica-Verlag HD: Heidelberg, Germany, 2002; pp. 25-34.

32. Lou, H.; Kulkarni, M.A.; Singh, A.; Huang, Y. A game theory based approach for emergy analysis of industrial ecosystem under uncertainty. Clean Technol. Environ. Policy 2004, 6, 156-161. [CrossRef]

33. Ehrenfeld, J.; Gertler, N. Industrial Ecology in Practice: The Evolution of Interdependence at Kalundborg. J. Ind. Ecol. 1997, 1, 67-79. [CrossRef]

34. Goldstein, J. Emergence as a Construct: History and Issues. Emergence 1999, 1, 49-72. [CrossRef]

35. Arthur, W.B. Increasing Returns and Path Dependence in the Economy; The University of Michigan Press: Ann Arbor, MI, USA, 1994.

36. David, P.A. Why are institutions the "carriers of history": Path dependence and the evolution of conventions, organizations and institutions. Struct. Chang. Econ. Dyn. 1994, 5, 205-220. [CrossRef]

37. Levin, S.A. Ecosystems and the Biosphere as Complex Adaptive Systems. Ecosystems 1998, 1, $431-436$. [CrossRef]

38. Choi, T.Y.; Dooley, K.J.; Rungtusanatham, M. Supply networks and complex adaptive systems: Control versus emergence. J. Oper. Manag. 2001, 19, 351-366. [CrossRef]

39. Capaldo, A.; Giannoccaro, I. How does trust affect performance in the supply chain? The moderating role of interdependence. Int. J. Prod. Econ. 2015, 166, 36-49. [CrossRef]

40. Capaldo, A.; Giannoccaro, I. Interdependence and network-level trust in supply chain networks: A computational study. Ind. Mark. Manag. 2015, 44, 180-195. [CrossRef]

41. Giannoccaro, I. Adaptive supply chains in industrial districts: A complexity science approach focused on learning. Int. J. Prod. Econ. 2015, 170, 576-589. [CrossRef]

42. Giannoccaro, I. Assessing the influence of the organization in the supply chain management using NK simulation. Int. J. Prod. Econ. 2011, 131, 263-272. [CrossRef]

43. Liwarska-Bizukojc, E.; Bizukojc, M.; Marcinkowski, A.; Doniec, A. The conceptual model of an eco-industrial park based upon ecological relationships. J. Clean. Prod. 2009, 17, 732-741. [CrossRef]

44. Seuring, S. Industrial ecology, life cycles, supply chains: Differences and interrelations. Bus. Strateg. Environ. 2004, 13, 306-319. [CrossRef]

45. Côté, R.; Hall, J. Industrial parks as ecosystems. J. Clean. Prod. 1995, 3, 41-46. [CrossRef]

46. Ashton, W.S. Managing Performance Expectations of Industrial Symbiosis. Bus. Strateg. Environ. 2011, 20, 297-309. [CrossRef]

47. Lyons, D. A Spatial Analysis of Loop Closing Among Recycling, Remanufacturing, and Waste Treatment Firms in Texas. J. Ind. Ecol. 2007, 11, 43-54. [CrossRef]

48. Fraccascia, L.; Albino, V.; Garavelli, C.A. Technical efficiency measures of industrial symbiosis networks using enterprise input-output analysis. Int. J. Prod. Econ. 2017, 183, 273-286. [CrossRef]

49. Yuan, Z.; Shi, L. Improving enterprise competitive advantage with industrial symbiosis: Case study of a smeltery in China. J. Clean. Prod. 2009, 17, 1295-1302. [CrossRef]

50. Sinding, K. Environmental management beyond the boundaries of the firm: Definitions and constraints. Bus. Strategy Environ. 2000, 9, 79-91. [CrossRef]

51. Yazan, D.M.; Fraccascia, L.; Albino, V.; Zijm, H. Cooperation in industrial symbiosis business models: An agent-based modelling approach. In Proceedings of the ISIE Americas Meeting 2016 “Industrial Ecology and Green Transformation", Bogotà, Colombia, 25-27 May 2016.

52. Axelrod, R. The Complexity of Cooperation: Agent-Based Models of Competition and Collaboration; Princeton University Press: Princeton, NJ, USA, 1997. 
53. Weiss, G. Multiagent Systems: A Modern Approach to Distributed Artificial Intelligence; The MIT Press: Cambrigde, MA, USA; London, UK, 1999.

54. Bonabeau, E. Agent-based modeling: Methods and techniques for simulating human systems. Proc. Natl. Acad. Sci. USA 2002, 99, 7280-7287. [CrossRef] [PubMed]

55. Macal, C.M.; North, M.J. Tutorial on agent-based modelling and simulation. J. Simul. 2010, 4, 151-162. [CrossRef]

56. Deissenberg, C.; van der Hoog, S.; Dawid, H. EURACE: A massively parallel agent-based model of the European economy. Appl. Math. Comput. 2008, 204, 541-552. [CrossRef]

57. Samanidou, E.; Zschischang, E.; Stauffer, D.; Lux, T. Agent-based models of financial markets. Rep. Prog. Phys. 2007, 70, 409-450. [CrossRef]

58. Rand, W.; Rust, R.T. Agent-based modeling in marketing: Guidelines for rigor. Int. J. Res. Mark. 2011, 28, 181-193. [CrossRef]

59. Shen, W.; Norrie, D.H. Agent-Based Systems for Intelligent Manufacturing: A State-of-the-Art Survey. Knowl. Inf. Syst. Int. J. 1999, 1, 129-156. [CrossRef]

60. Albino, V.; Carbonara, N.; Giannoccaro, I. Innovation in industrial districts: An agent-based simulation model. Int. J. Prod. Econ. 2006, 104, 30-45. [CrossRef]

61. Jiao, J.; You, X.; Kumar, A. An agent-based framework for collaborative negotiation in the global manufacturing supply chain network. Robot. Comput. Integr. Manuf. 2006, 22, 239-255. [CrossRef]

62. Albino, V.; Carbonara, N.; Giannoccaro, I. Supply Chain Management models for Industrial Districts: An Agent-Based Simulation study. Int. J. Intell. Syst. Technol. Appl. 2009, 6, 332-348. [CrossRef]

63. Albino, V.; Carbonara, N.; Giannoccaro, I. Supply chain cooperation in industrial districts: A simulation analysis. Eur. J. Oper. Res. 2007, 177, 261-280. [CrossRef]

64. Batten, D.F. Fostering Industrial Symbiosis With Agent-Based Simulation and Participatory Modeling. J. Ind. Ecol. 2009, 13, 197-213. [CrossRef]

65. Romero, E.; Ruiz, M.C. Proposal of an agent-based analytical model to convert industrial areas in industrial eco-systems. Sci. Total Environ. 2014, 468-469, 394-405. [CrossRef] [PubMed]

66. Yazdanpanah, V.; Yazan, D.M.; Zijm, W.H.M. Normative Industrial Symbiotic Networks: A Position Paper. In Proceedings of the 14th European Conference on Multi-Agent Systems, Valencia, Spain, 14-19 December 2016.

67. Cao, K.; Feng, X.; Wan, H. Applying agent-based modeling to the evolution of eco-industrial systems. Ecol. Econ. 2009, 68, 2868-2876. [CrossRef]

68. Chertow, M.R.; Lombardi, D.R. Quantifying Economic and Environmental Benefits of Co-Located Firms. Environ. Sci. Technol. 2005, 39, 6535-6541. [CrossRef] [PubMed]

69. Deutz, P.; Ioppolo, G. From Theory to Practice: Enhancing the Potential Policy Impact of Industrial Ecology. Sustainability 2015, 7, 2259-2273. [CrossRef]

70. Lehtoranta, S.; Nissinen, A.; Mattila, T. Industrial symbiosis and the policy instruments of sustainable consumption and production. J. Clean. Prod. 2011, 19, 1865-1875. [CrossRef]

71. Van Berkel, R.; Fujita, T.; Hashimoto, S.; Fujii, M. Quantitative Assessment of Urban and Industrial Symbiosis in Kawasaki, Japan. Environ. Sci. Technol. 2009, 43, 1271-1281. [CrossRef] [PubMed]

72. Park, J.M.; Park, J.Y.; Park, H.-S. A review of the National Eco-Industrial Park Development Program in Korea: Progress and achievements in the first phase, 2005-2010. J. Clean. Prod. 2016, 114, 33-44. [CrossRef]

73. Trokanas, N.; Cecelja, F.; Raafat, T. Semantic input/output matching for waste processing in industrial symbiosis. Comput. Chem. Eng. 2014, 66, 259-268. [CrossRef]

74. Luciano, A.; Barberio, G.; Mancuso, E.; Sbaffoni, S.; La Monica, M.; Scagliarino, C.; Cutaia, L. Potential Improvement of the Methodology for Industrial Symbiosis Implementation at Regional Scale. Waste Biomass Valoriz. 2016, 7, 1007-1015. [CrossRef]

75. Yazan, D.M.; Romano, V.A.; Albino, V. The design of industrial symbiosis: An input-output approach. J. Clean. Prod. 2016, 129, 537-547. [CrossRef]

76. Yazan, D.M. Constructing joint production chains: An enterprise input-output approach for alternative energy use. Resour. Conserv. Recycl. 2016, 107, 38-52. [CrossRef]

77. Yang, S.; Feng, N. A case study of industrial symbiosis: Nanning Sugar Co., Ltd. in China. Resour. Conserv. Recycl. 2008, 52, 813-820. [CrossRef] 
78. Zhu, Q.; Lowe, E.A.; Wei, Y.; Barnes, D. Industrial Symbiosis in China: A Case Study of the Guitang Group. J. Ind. Ecol. 2007, 11, 31-42. [CrossRef]

79. Pathak, S.D.; Day, J.M.; Nair, A.; Sawaya, W.J.; Kristal, M.M. Complexity and Adaptivity in Supply Networks: Building Supply Network Theory Using a Complex Adaptive Systems Perspective. Decis. Sci. 2007, 38, 547-580. [CrossRef]

80. Reeves, M.; Deimler, M. Adaptability: The New Competitive Advantage. Harward Bus. Rev. 2011, 89, 134-141.

81. Organisation for Economic Co-operation and Development (OECD). Addressing the Economics of Waste; OECD: Paris, France, 2004.

82. Ferrara, I.; Missios, P. Recycling and Waste Diversion Effectiveness: Evidence from Canada. Environ. Resour. Econ. 2005, 30, 221-238. [CrossRef]

83. Zaman, A.U.; Lehmann, S. Urban growth and waste management optimization towards "zero waste city". City Cult. Soc. 2011, 2, 177-187. [CrossRef]

84. Ajayi, S.O.; Oyedele, L.O.; Bilal, M.; Akinade, O.O.; Alaka, H.A.; Owolabi, H.A.; Kadiri, K.O. Waste effectiveness of the construction industry: Understanding the impediments and requisites for improvements. Resour. Conserv. Recycl. 2015, 102, 101-112. [CrossRef]

85. Yuan, H.; Wang, J. A system dynamics model for determining the waste disposal charging fee in construction. Eur. J. Oper. Res. 2014, 237, 988-996. [CrossRef]

86. Nicolli, F.; Mazzanti, M. Landfill diversion in a decentralized setting: A dynamic assessment of landfill taxes. Resour. Conserv. Recycl. 2013, 81, 17-23. [CrossRef]

87. Calvo, N.; Varela-Candamio, L.; Novo-Corti, I. A Dynamic Model for Construction and Demolition (C\&D) Waste Management in Spain: Driving Policies Based on Economic Incentives and Tax Penalties. Sustainability 2014, 6, 416-435.

88. Mazzanti, M.; Montini, A.; Nicolli, F. The dynamics of landfill diversion: Economic drivers, policy factors and spatial issues. Resour. Conserv. Recycl. 2009, 54, 53-61. [CrossRef]

(C) 2017 by the authors. Licensee MDPI, Basel, Switzerland. This article is an open access article distributed under the terms and conditions of the Creative Commons Attribution (CC BY) license (http:/ / creativecommons.org/licenses/by/4.0/). 